\title{
PROGRAM ARSITEKTUR SEBAGAI PEMBENTUK TEMPAT KETIGA DI PASAR BARU
}

\author{
Denzel Suptan ${ }^{1)}$, Denny Husin ${ }^{2)}$ \\ 1)Program Studi S1 Arsitektur, Fakultas Teknik, Universitas Tarumanagara, denzel.sanusi@gmail.com \\ ${ }^{2)}$ Program Studi S1 Arsitektur, Fakultas Teknik, Universitas Tarumanagara, denny@ft.untar.ac.id
}

\begin{abstract}
Abstrak
Fenomena kebutuhan akan pelengkap aktivitas keseharian masyarakat kota di suatu daerah perlu untuk direspon ke dalam strategi desain yang dapat menyelesaikan berbagai macam konflik. Hal tersebut tentunya terjadi di kota Jakarta yang masih terdapat masalah minimnya fasilitas ruang publik dan kurang menjangkau area permukiman. Isu bahwa wilayah memiliki karakteristiknya sendiri yang juga memunculkan berbagai aktivitas selain kegiatan rutinitas sehari-hari berupa ragam kegiatan hiburan, niaga, bahkan ada kegiatan yang menampung berbagai event/acara-acara menjadi latar belakang studi. Tujuan penelitian ini adalah mengangkat ruang publik sebagai ruang pemersatu atau transisi dari rutinitas rumah (first place) dan pekerjaan (second place). Metode programming cross, trans, dan dis digunakan dengan tidak menghilangkan atau mengubah secara total berbagai hal yang sudah menjadi karakteristik dari kawasan, dengan cara mempelajari aktivitas-aktivitas yang mungkin bisa diaktifkan kembali lalu disimulasikan. Secara hipotesis Pasar Baru dapat berperan kembali mewujudkan identitas fisik sebagai kota lama agar dapat terus hidup dan berkesinambungan. Langkah yang digunakan yaitu menyisipkan event tertentu pada celah yang kosong dengan metode penyisipan program. Temuannya berupa event program dapat terus terhubung di setiap waktu melalui program-program yang disisipkan. Hasil proyek tempat ketiga ini menunjukkan bahwa arsitektur dapat turut serta berkontribusi dalam mengupayakan pengembangan program.
\end{abstract}

\section{Kata kunci: Program; Ruang Ketiga; Transisi}

\begin{abstract}
The phenomenon of the need to complement the daily activities of urban communities in an area need to be responded to in a design strategy that can resolve various kinds of conflicts. This is happening in Jakarta where there were still problems with the lack of public space facilities that not reach the residential area. The issue that the region has its characteristics that also raises a variety of activities in addition to daily routine activities in the form of a variety of entertainment activities, commerce, and even some activities accommodate various events. The purpose of this study is to raise public space as a unifying space or transition from routine home (first place) and work (second place). Cross, trans, and dis programming methods are used by not eliminating or changing things that are already characteristic of the region, by studying activities that might be reactivated and then simulated, hypothetically Pasar Baru can play a role in realizing physical identity as the old city to continue to live and be sustainable. The step used is to insert certain events in an empty slot in a year with the program insertion method. The findings are that program events can continue to be connected at all times through embedded programs. The results of this third place project show that architecture can contribute to the development of the program.
\end{abstract}

\section{Keywords: Program; Third Place; Transition}




\section{PENDAHULUAN}

\section{Latar Belakang}

Kota Jakarta merupakan kota metropolitan yang mempunyai fungsi sangat strategis. Fungsi Kota Jakarta selain sebagai pusat pemerintahan juga merupakan pusat bisnis dan perdagangan (Rieswari, 2002). Sebagai kota yang telah sangat berkembang kemajuannya dibandingkan kotakota lain di Indonesia, maka perkembangan kota harus dapat mempertahankan fitur-fitur kearifan lokalnya dalam rumusan baru yang tepat agar masa depan kota dapat lebih berkelanjutan (Daniel, et al., 2015). Di samping itu, kebutuhan akan pelengkap aktivitas keseharian masyarakat kota di suatu daerah perlu untuk direspon ke dalam strategi desain yang dapat menyelesaikan berbagai macam konflik melalui program yang terbentuk dengan tujuan membantu masyarakat kota agar bersifat humanis, terbuka, dinamis dan produktif. Hal tersebut tentunya terjadi di lingkungan Kelurahan Pasar Baru, Jakarta Pusat di mana terdapat sebagian wilayah dengan minimnya fasilitas publik terutama di sekitar area permukiman warga. Ruang publik merupakan suatu bentuk ruang pertemuan yang baru, modern, dan berkembang seperti halnya pusat perbelanjaan yang bukan hanya sebagai fasilitas komersial melainkan muncul dengan adanya tuntutan sosial, kebutuhan akan rasa aman, kebutuhan gaya hidup perkotaan, strategi penjual, dan lain-lain (Hantono \& Ariantantrie, 2018). Melihat dari kebutuhan akan ruang berkumpul, bermain serta hiburan warga yang tentunya sudah melalui proses pengamatan dan pencarian informasi dari berbagai sumber, alhasil disimpulkan bahwa pusat kegiatan yang berada di Kelurahan Pasar Baru nyatanya kurang menjangkau permukiman di Kelurahan Pasar Baru, dalam artian belum terdapat ruang pemersatu atau transisi dari komersial dengan pemukiman.

Secara keseluruhan, Kelurahan Pasar Baru dikenal sebagai kawasan melting pot dari para pemilik toko-toko dan pengunjung dari bermacam-macam latar belakang dan budaya di Kota Batavia seperti Belanda, Tiongkok, India, Pakistan dan Melayu (Wicaksono, 2014). Terlihat keragaman tersebut juga memunculkan berbagai aktivitas selain kegiatan niaga berupa ragam kegiatan hiburan, budaya dan keagamaan yang sempat terhenti dan pamor Pasar Baru pun mulai memudar. Pasar Baru juga berperan sebagai ruang publik yang menampung berbagai event/acara-acara berdasarkan keragaman budaya dan etnis. Fenomena yang terjadi di ruang publik ini bisa dipahami sebagai sebuah event. Event di sini bukanlah event besar yang dilangsungkan dengan persiapan khusus untuk merayakan sesuatu. Namun, pemahaman event di sini lebih kepada bagaimana fenomena tersebut hadir. Event yang berarti sesuatu yang terjadi pada titik tertentu pada ruang dan pada kurun waktu tertentu pula dan setiap individu bisa dengan bebas memahami setiap elemen ruang yang hadir untuk kemudian menentukan 'titik' dimulainya event tersebut (Hawking, 1988).

Isu dan tantangan yang terdapat di Kelurahan Pasar Baru adalah adanya sebuah ketidaksinambungan antara permukiman yang ada di sekitar dengan pusat komersial perbelanjaan Pasar Baru. Padahal lingkungan Pasar Baru yang terletak di bagian tengah Kota Jakarta telah menjadi suatu bagian kota yang padat bangunan dengan berbagai macam aktivitas penduduknya, sehingga lingkungan ini dapat disebut sebagai suatu urban area dengan kondisi pemukiman yang stabil (Indra, 2009). Selain itu, Indra juga membahas bahwa memasuki abad ke-19, jumlah penduduk dan bangunan tempat tinggal maupun bangunan untuk kepentingan umum semakin bertambah dan mengalami perkembangan kegiatan menjadi kegiatan perdagangan. Untuk itu, tumbuhnya kota di antaranya juga sebagai usaha untuk menyediakan fasilitas-fasilitas umum bagi penduduk kota itu sendiri (Pasya, 2012). Di samping fenomena Pasar Baru yang mulai menghilang pamornya, seharusnya permukiman yang ada dengan Pasar Baru saling mendukung, akan tetapi setelah dilakukan pengamatan nyatanya tidak berkesinambungan. Dalam artian belum terdapat ruang pemersatu atau transisi dari komersial dengan pemukiman. 


\section{Rumusan Permasalahan}

Kawasan permukiman yang kurang mendukung fasilitas umum yang ada di sekitar permukiman membuat terputusnya hubungan komersial dan pemukiman berakibat tidak adanya gradasi ruang antara dua jenis peruntukan yang berbeda. Fungsi permukiman dapat dilihat dari kondisi masing-masing unsur penyusun atau komponen yang menggambarkan bagaimana kondisi permukiman tersebut secara keseluruhan (Setiawan, Astuti, \& Rini, 2017). Dalam hal ini dilema Pasar Baru mengenai akses kendaraan dan pedestrian. Berbagai hal disebabkan tidak beraturannya pedagang kaki lima yang berjualan disepanjang jalan Pasar Baru, kurangnya ruang terbuka, kurangnya fasilitas umum yang tersedia, sirkulasi jalan yang tidak terorientasi, pedestrian yang tidak mendukung, lahan parkir yang minim (Nurun, 2013). Dengan demikian kawasan Pasar Baru semakin memudarkan pamor kejayaannya, ditambah banyak bangunan yang mencerminkan kejayaan Pasar Baru di masa lalu menjadi tidak terawat. Sehingga, bagaimana

\section{Tujuan}

Studi ini bertujuan untuk memberikan usulan atas rumusan permasalahan melalui rancangan proyek yang mampu mewadahi kegiatan dan aktivitas pengguna sebagai wadah "tempat ketiga". Tujuan lainnya yaitu; menghadirkan program yang terbentuk dari usulan alternatif keruangan tempat ketiga agar menjadi wadah pemersatu antara permukiman warga dengan fasilitas publik lainnya berupa fasilitas pendidikan, perbelanjaan, tempat ibadah, serta seni dan budaya bagi masyarakat semua kalangan usia dalam berkumpul, melakukan aktivitas baik itu pagi, siang, hingga malam hari. mengingat area perbelanjaan di Pasar Baru tidak aktif pada malam hari sehingga bisa menghidupkan sebagian kawasan kelurahan Pasar Baru, serta mengajak warga untuk tidak berdiam terus di dalam hunian yang dapat mengakibatkan efek kejenuhan. Berbagai visi dari proyek yang ditujukan tidak menghilangkan atau mengubah secara total berbagai hal yang sudah menjadi karakteristik dari kawasan, akan tetapi dikembangkan agar proyek dapat menjadi aksen untuk menarik pergerakan pengunjung dari first place (rumah) menuju second place (bekerja).

\section{KAJIAN LITERATUR}

\section{Open Architecture - Tempat Ketiga (Third Place)}

Open architecture tidak terlepas dari dua hal, yakni open society dan open city. Open City adalah istilah yang agak utopis: ini mengacu pada upaya arsitek dan perancang kota untuk menerjemahkan cita-cita "Open Society"; di mana beragam kelompok mengembangkan mekanisme yang fleksibel untuk menyelesaikan perbedaan ke dalam ruang fisik terkait konteks kebutuhan masyarakat kota yang berorientasi pada teknologi, informasi, dan individu". "Third Place" merupakan tempat beraktivitas di luar rumah (first place) serta tempat kerja dan belajar (second place) guna memenuhi hubungan sosial dengan orang lain serta sebagai tempat rekreasi di waktu luang (Oldenburg, 1989). ${ }^{2}$ Winata juga menyatakan bahwa tempat ketiga perlu terbuka bagi siapa saja tanpa melihat latar belakang masing individu maupun komunitasnya. Namun, keterbukaan ini tetap perlu berkonteks pada sosial masyarakat kota termasuk keragamannya. Third Place juga harus bisa dilihat dalam konteks urban yang kuat. Di sinilah peran arsitektur dalam menciptakan permeabilitas, yaitu rembesan pergerakan orang yang terjadi dari first place menuju second place. Alhasil, peran third place bekerja mengalirkan pergerakan orang tersebut ${ }^{3}$.

\footnotetext{
${ }^{1}$ Herlambang, Suryono. (2020, Januari 16). Open Society-Open City-Open Architecture. Dipresentasikan pada kuliah umum, Universitas Tarumanagara.

2 Winata, Suwardana. (2019). Open Architecture As. Dipublikasikan pada pameran arsitektur virtual STUPA 8.29, Universitas Tarumanagara: 4 Juli 2020.

3 Sutanto, Agustinus. (2020, Januari 16). Architecture of the Third Place. Dipresentasikan pada kuliah umum, Universitas Tarumanagara.
} 


\section{Ruang dan Tempat}

Third Place berkaitan dengan space (ruang) dan place (tempat), dua kata yang selalu dibahas dalam dunia arsitektur. Penggunaannya di dalam pembahasan terhadap suatu topik arsitektur tidak jarang terkesan 'campur aduk' sehingga membiaskan makna dari masing-masing kata tersebut. Namun dalam pembahasan ini lebih ditekankan pada bagaimana manusia merasakan (feel) dan mengalami (experience) ruang dan tempat tersebut. Yi Fu Tuan berpendapat bahwa ruang lebih abstrak dari tempat. Pendapat ini berarti tempat hanya bisa hadir apabila ada ruang sebagai dasar pembentukannya (Fikri, 2016). Namun, pendapat berbeda menyatakan bahwa tempat justru menjadi dasar dari kehadiran sebuah ruang (Certeau, 1984). Oleh sebab itu, pemahaman tentang ruang dan tempat yang dikemukakan oleh Certeau yang akan digunakan sebagai dasar dalam berbagai pembahasan selanjutnya. Pemilihan ini didasari karena membahas bagaimana sebuah tempat yang sama akan digunakan secara berulang kali oleh berbagai individu yang berbeda di berbagai kondisi.

\section{Aktivitas dan Event}

Kehadiran dari sebuah ruang publik di kehidupan sehari-hari memberi kesempatan warga kota untuk bertemu dan berinteraksi, menciptakan berbagai aktivitas. Fenomena yang terjadi di ruang publik ini bisa dipahami sebagai sebuah event. Event di sini bukanlah event besar yang dilangsungkan dengan persiapan khusus untuk merayakan sesuatu. Namun pemahaman event di sini lebih kepada bagaimana fenomena tersebut hadir. Event merupakan suatu kegiatan yang diselenggarakan untuk memperingati hal-hal penting sepanjang hidup manusia baik secara individu atau kelompok yang diselenggarakan pada waktu tertentu (Noor, 2009). Tiap individu kemudian akan membentuk ruang hasil dari pergerakan mereka masing-masing dalam sebuah kondisi tertentu yang disebut event (Tschumi, 1994). Dari berbagai pendapat definisi event, maka didapat dua pandangan bahwa event untuk merayakan acara tertentu dan event yang hadir dari fenomena.

\section{Ephemeral dan Temporal}

Sebuah tempat bisa berubah menjadi berbagai macam ruang yang berbeda, tergantung dari event yang berlangsung di tempat tersebut. Ruang tersebut terbentuk ketika event tersebut muncul, ketika event tersebut selesai, maka ruang yang terbentuk juga ikut menghilang. Pemahaman baru tentang event dan ruang berhubungan dengan konsep ruang ephemeral (Septian, Kurniati, \& Maharika, 2017). Ephemeral dalam berarsitektur sudah ada sejak manusia pertama kali berarsitektur. Akan tetapi, teori ini baru ditemukan dan didefinisikan lebih mendalam batasan dari ephemeral architecture. Konsep tentang ruang ephemeral secara sederhana merupakan ruang yang hanya muncul sesaat, layaknya event yang hanya muncul pada waktu-waktu tertentu (Bonnemaison \& Masy, 2008). Konsep tentang ruang ephemeral ini yang kemudian coba dibawa ke dalam konteks Kelurahan Pasar Baru. Selain itu, pemahaman ruang ephemeral ini sering bercampur dengan 'temporal' yang mana keduanya saling berhubungan karena sama-sama memiliki parameter waktu. Namun, ephemeral memiliki sifat yang lebih fleksibel. Ephemeral bisa terjadi kapan saja secara spontan, dan bisa berlangsung dalam kurun waktu yang sangat singkat, bahkan mungkin hanya dalam hitungan menit.

\section{METODE}

\section{Deduktif dan Partisipatoris}

Metode riset yang dilakukan berupa pendekatan deduktif. Sumbernya berdasarkan pada pengetahuan sebelumnya yang bersifat umum serta menyimpulkan pengetahuan baru yang bersifat khusus (Mardiyantoro, 2019). Dalam hal ini melalui literatur dan media elektronik dalam mencari dan mengumpulkan data. Untuk melengkapi proses pengumpulan data, 
dilakukan metode pendekatan melalui sudut pandang permasalahan warga di kelurahan Pasar Baru melalui survey lapangan dengan mengamati situasi dan kondisi area permukiman, fasilitas publik, serta karakteristik Kelurahan Pasar Baru. Selain itu, metode partisipatoris digunakan dalam proses wawancara melalui tatap muka dan tanya jawab langsung antara penulis dan narasumber. Partisipatori berasal dari kata partisipasi yaitu perlibatan seseorang atau beberapa orang pada suatu kegiatan (Pidarta, 2015), dalam hal ini yang bersangkutan adalah ketua RT 11 dan salah satu kepala keluarga RW 05 di Jl. Gg. Mandor III; anak-anak RW 04, 05, 08 yang sedang bermain; serta salah satu pedagang pasar di basement gedung metro atom Pasar Baru. Data hasil dari pengamatan dan wawancara yang berfokus pada permasalahan dijadikan acuan dasar dalam perancangan proyek ini.

\section{Penyisipan dan Penggabungan Program}

Untuk menciptakan konsep event dan ruang epehemeral pada rancangan proyek, maka metode perancangan berfokus pada penggabungan berbagai program guna mengetahui hubungan atau konfigurasi antar ruang (Arsitektur Dekonstruktif) dalam merefleksikan metode perancangan ke dalam konsep. Aliran dekonstruktif mengandung unsur space (ruang), event (peristiwa) dan movement (pergerakan) yang disjunctive (terpisah). Dekonstruksi juga memberikan apresiasi terhadap keragaman, eksplorasi ide dan teknik tanpa aturan sehingga unsur kebaruan mudah diperoleh (Yusa, 2016). Dalam mengolah ruang, event, dan pergerakan tersebut berkaitan dengan penggabungan berbagai program (Tschumi, 2005). Untuk itu, fokus penggabungan berbagai program sejalan dengan pengembangan program berskala urban di Kelurahan Pasar Baru untuk diaplikasikan pada event-event tahunan, bulanan, maupun harian. Kemudian metode pendekatan program-program tersebut yang nantinya dikombinasikan dan diwujudkan melalui strategi desain yang akan dijabarkan selanjutnya. Metode desain secara umum yang ditekankan di sini yaitu event untuk skala urban sedangkan program untuk skala bangunan sehingga menciptakan arsitektur yang memiliki program yang dapat berubah sesuai dengan perubahan waktu yang mana dalam hal ini dalam satu harinya atau dari pagi hingga malam.

Tabel 1. Prinsip dan Metode Penggabungan Program Bernard Tschumi

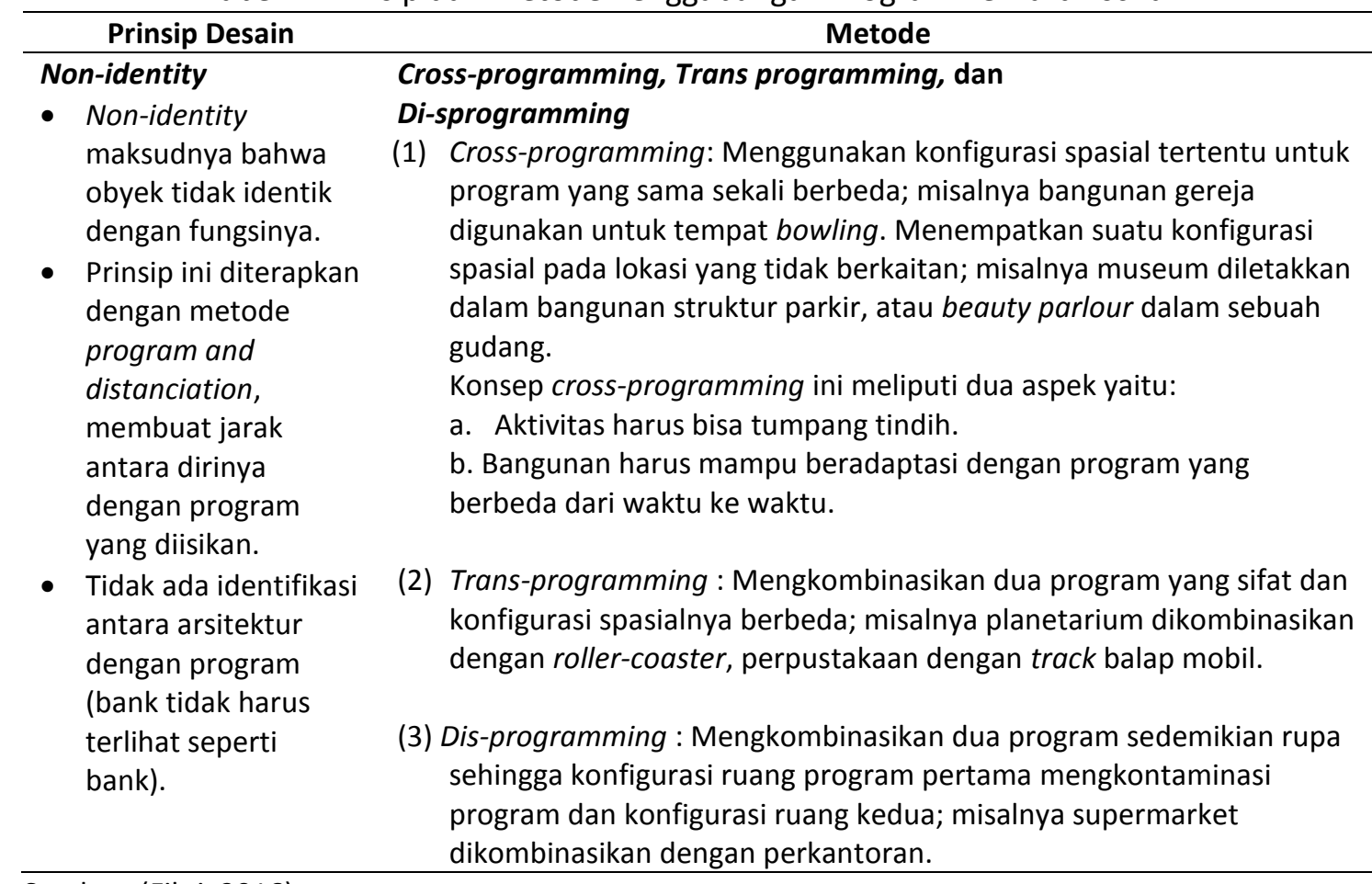

Sumber: (Fikri, 2016) 


\section{DISKUSI DAN HASIL}

\section{Pemilihan Lokasi}

Lokasi proyek berada di Kelurahan Pasar Baru, Jakarta Pusat yang berkembang secara alamiah berbasis kehidupan bermasyarakat di dalamnya. Kelurahan Pasar Baru harus dilihat secara menyeluruh sebagai suatu kawasan mixed use yang terdiri dari hunian, fasilitas umum, tempat bekerja dan perniagaan. Kelurahan ini identik dengan kearifan budaya, multi etnis (India, Tionghoa, Melayu) serta agama (Islam, Kristen Protestan, Hindu, dan Budha). Lokasi tapak perancangan dipilih atas dasar kontekstualitas ruang yang mampu menjawab rumusan masalah serta visi dari proyek ini. Di sisi lain, terdapat kampung kota yang tengah menghadapi dominasi pembangunan oleh kelas sosial menengah ke atas. Keberagaman lapisan masyarakat sebagai aktor dan pelaku kegiatan ruang sosial di dalamnya menjadi semakin menarik. Sehingga cukup berpotensi dalam memberi tanggapan atas ruang arsitektur seperti apa yang dapat berubah sesuai perubahan waktu dan acara.

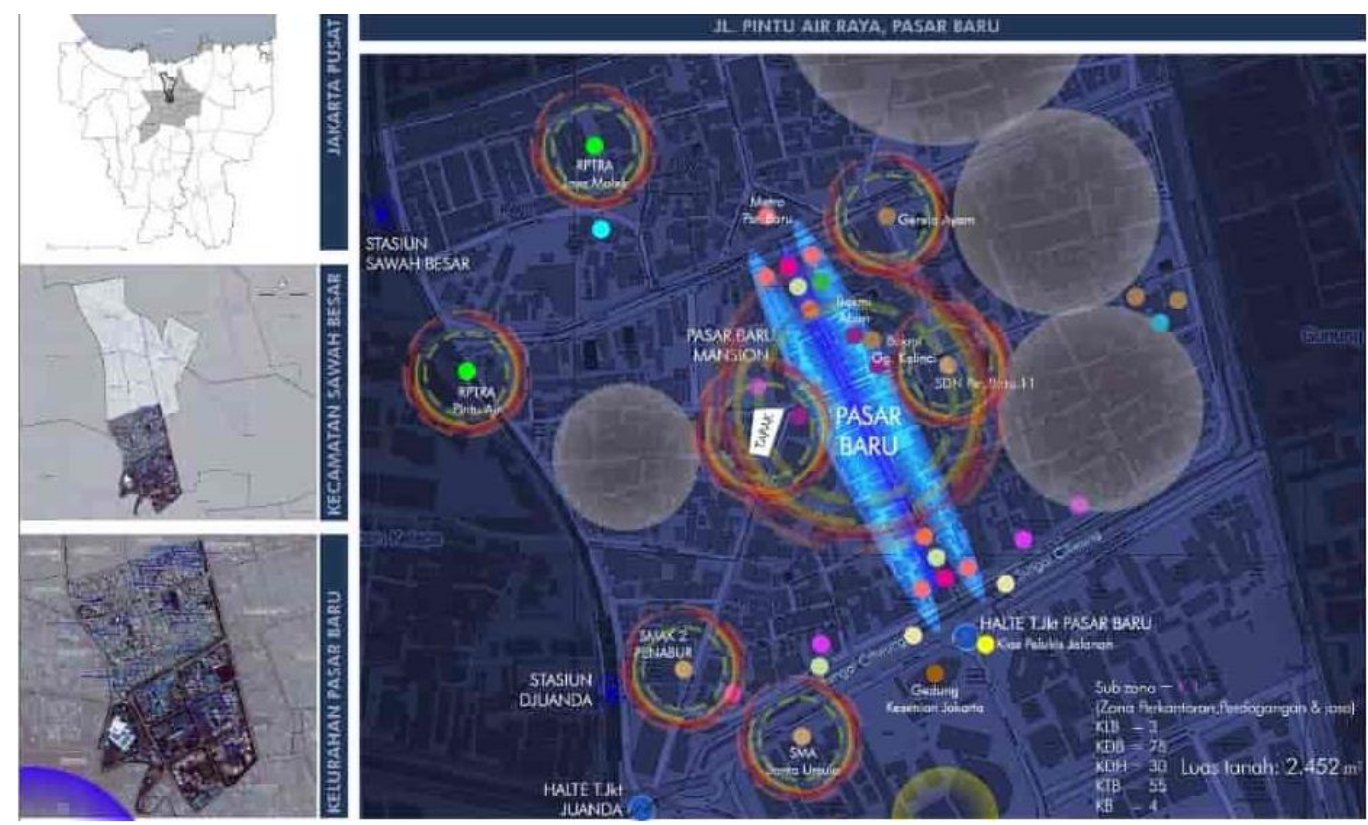

Gambar 1. Lokasi Kelurahan Pasar Baru

Sumber: https://openstreetmap.id/peta-kelurahan-kelurahan-di-jakarta-pusat-2/, diunduh 19 Januari 2020 - Digambar ulang oleh Penulis, 2020

\section{Tapak}

Melihat dari isu dan masalah terkait permukiman di Kelurahan Pasar Baru, maka ditentukan kriteria lokasi tapak yang memungkinkan untuk dijadikan proyek Third Place sebagai berikut.

a. Lokasi proyek dapat dijangkau dengan mudah oleh warga di Kelurahan Pasar Baru dan juga untuk pengunjung lainnya dengan berjalan kaki (minimal radius $\mathbf{3 0 0}$ meter dari hunian di Kelurahan Pasar Baru).

b. Dekat dengan hunian, fasilitas pendidikan, tempat kerja (di pusat perbelanjaan Pasar Baru), serta titik pemadam kebakaran dan pos polisi.

Berdasarkan rencana zonasi, Kelurahan Pasar Baru didominasi oleh peruntukan lahan komersial, campuran, dan pemerintahan, sedangkan zona hunian cukup sedikit. Lokasi tapak dipilih di dekat pusat belanja Pasar Baru tepatnya di Jl. Pintu Air Raya karena area tersebut menjadi fokus utama dalam penyediaan fasilitas pelengkap publik selain pendatang. Selain itu lokasi tapak juga berperan sebagai pemersatu fasilitas warga di Kelurahan Pasar Baru khususnya lingkungan permukiman dengan fasilitas umum berupa fasilitas pendidikan, perbelanjaan, tempat ibadah, serta seni dan budaya yang ada di Kelurahan Pasar Baru. 


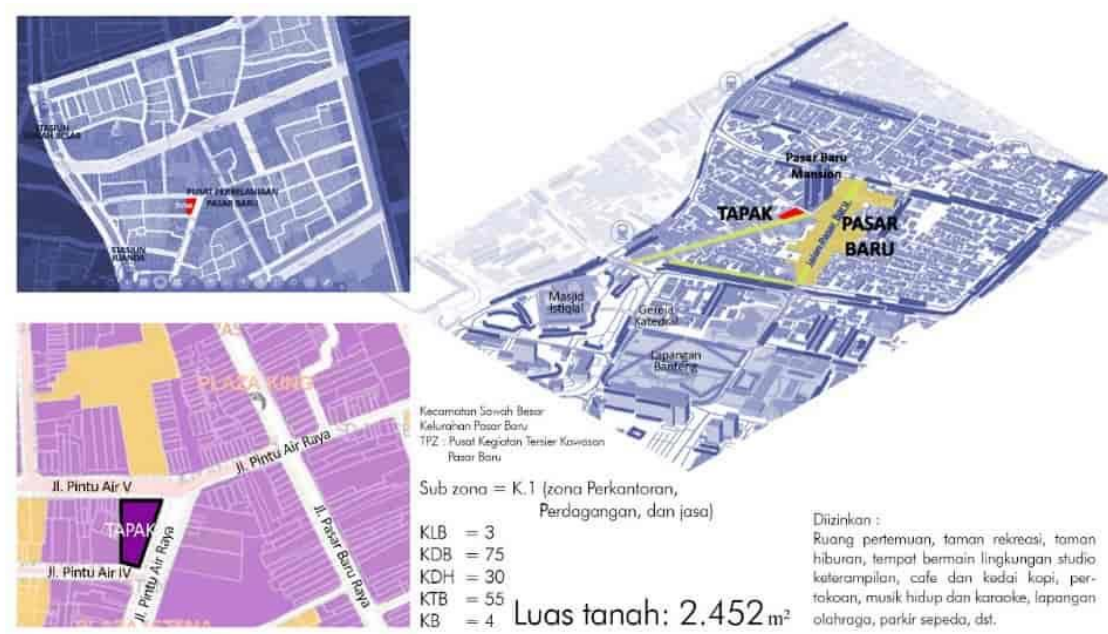

Gambar 2. Lokasi dan Spesifikasi Tapak

Sumber:

https://jakartasatu.jakarta.go.id/portal/apps/webappviewer/index.html?id=1c1bfcced2cb4852bbeaefcd

968a6d04, diunduh 8 Februari 2020 - Digambar ulang oleh Penulis, 2020

\section{Konsep}

Berdasarkan identifikasi lokasi tapak yang sudah dijabarkan sebelumnya, pemetaan beberapa event-event pada fungsi bangunan pun dilakukan agar kehadiran proyek ini dapat mempengaruhi lingkungan sekitarnya. Fenomena yang terjadi di samping pamor Pasar Baru yang mulai memudar, aktivitas/event-event yang dulunya rutin dilakukan nyatanya sekarang tidak, sehingga konsep yang ditekankan di sini yaitu event untuk skala urban sedangkan program untuk skala bangunan. Konsep merancang proyek "Fasilitas Komersial Kreatif Pasar Baru" dimulai dari memilah kondisi eksisting tapak dan diklasifikasikan ke dalam tiga kategori, yaitu dari segi urbanisme, transformasi massa, dan arsitektur yang akan dituangkan dalam bentuk diagram-diagram. Masing-masing dari kategori ini akan ditautkan lagi dengan metode programming cross, trans, dan dis, sehingga hasil yang didapatkan merupakan serangkaian proses berpikir yang saling terkait. Strategi desain yaitu mempelajari aktivitas-aktivitas yang mungkin bisa diaktifkan kembali lalu disimulasikan dengan metode penyisipan program. Di bawah ini terdapat kerangka proses perancangan (lih. Gambar 4).

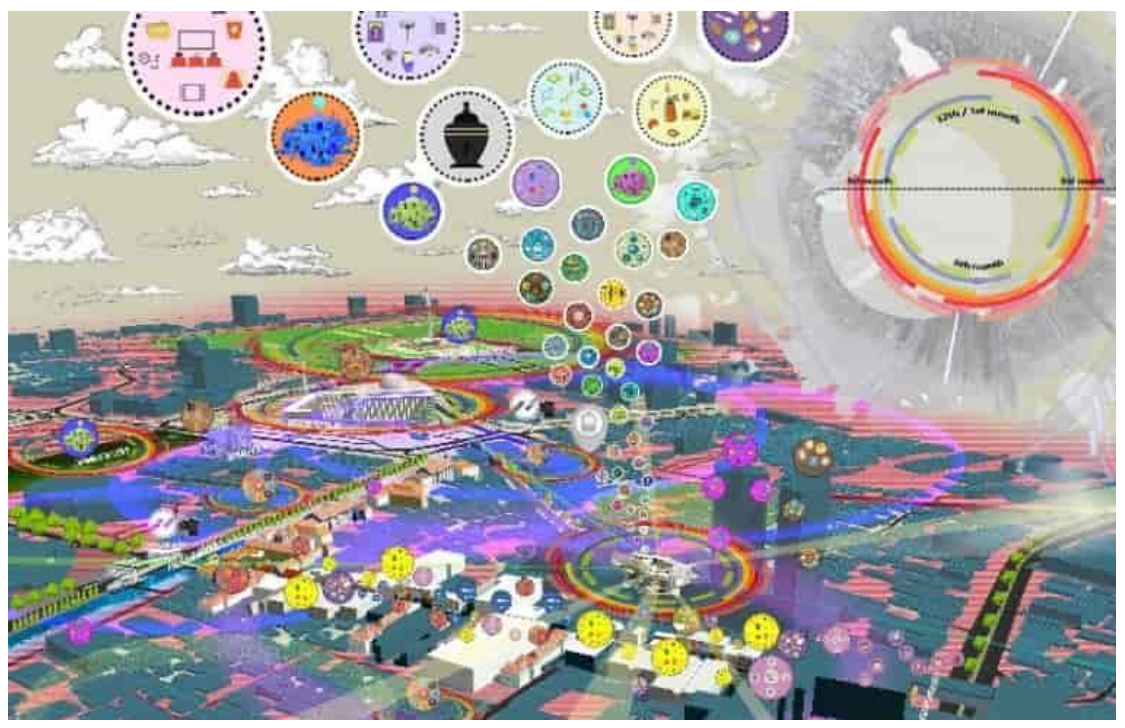

Gambar 3. Implementasi Strategi Urban

Sumber: Penulis, 2020 


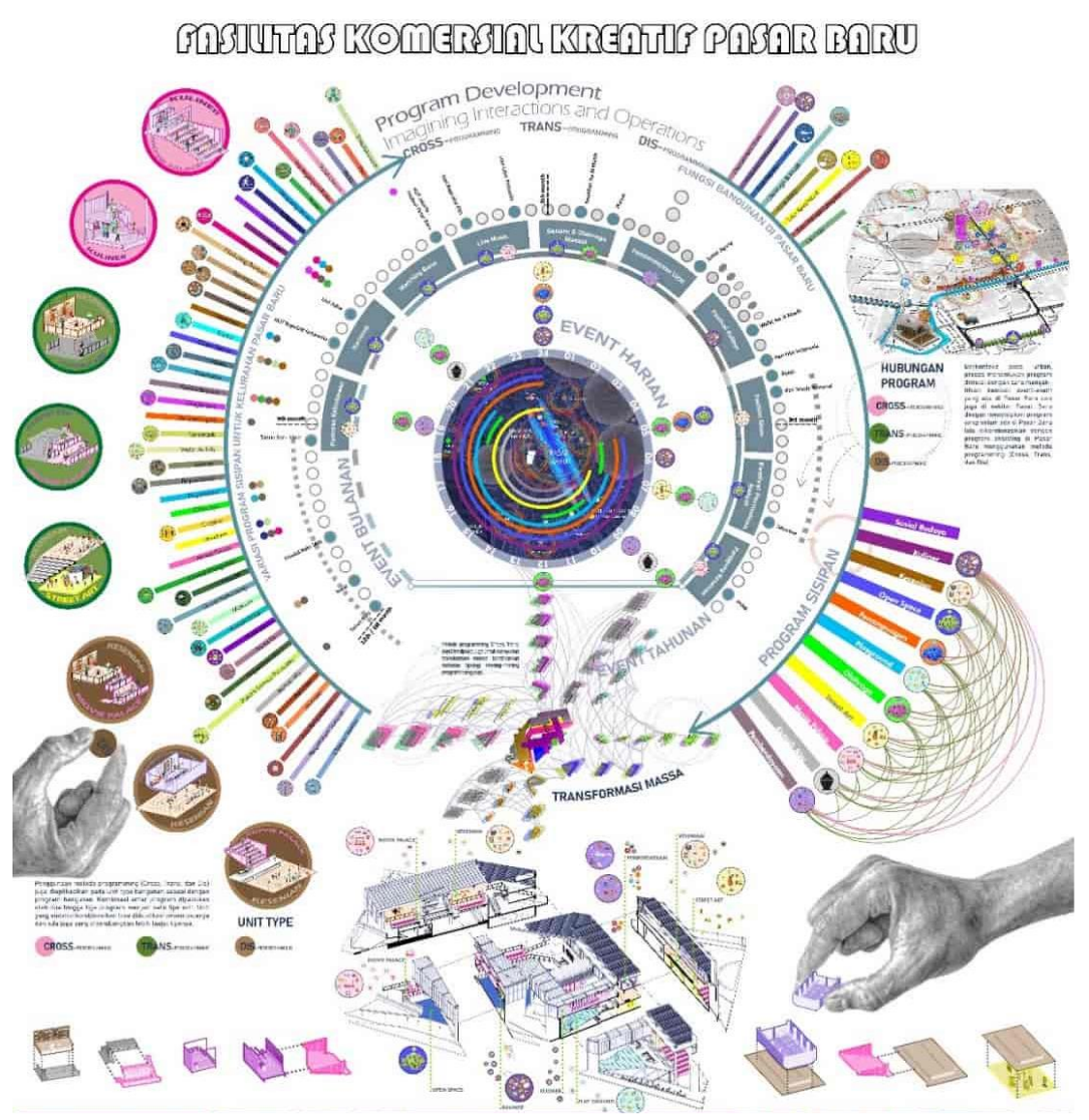

Gambar 4. Kerangka Proses Perancangan

Sumber: Penulis, 2020

Kerangka proses perancangan pada Gambar 4 berbasis pada tiga kategori klasifikasi ke dalam tiga proses utama perancangan yakni penentuan program, proses transformasi massa, dan konsep arsitektur berkaitan dengan tipe unit.

\section{Konsep Urbanisme}

Berkonteks pada urban, proses menentukan program dimulai dengan cara mengaktifkan kembali event-event yang ada di Pasar Baru dan juga di sekitar Pasar Baru dengan menyisipkan 50 program yang belum ada di Pasar Baru lalu dikombinasikan dengan program eksisting di Pasar Baru menggunakan metode programming (cross, trans, dan dis). Kelima puluh program yang akan disisipkan tersebut tampak pada gambar 6 . Berdasarkan hasil simulasi penyisipan program, maka didapat beberapa program sisipan yang akan digabungkan ke dalam program bangunan untuk melengkapi event-event sekitar yang bisa diaktifkan. Adapun program bangunan tersebut tampak pada Gambar 5.
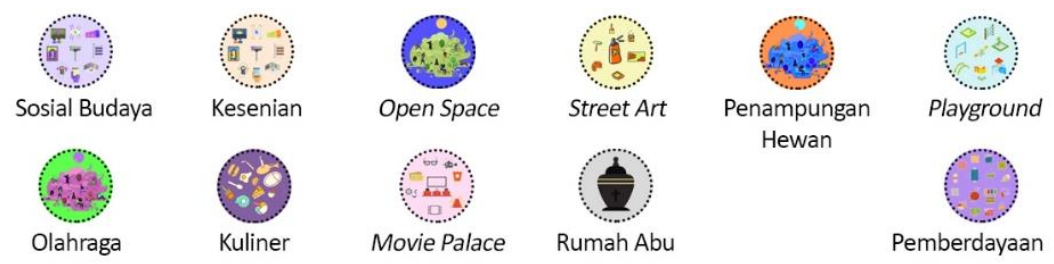

Hewan

PROGRAM SISIPAN PADA BANGUNAN

Gambar 5. Program Sisipan pada Bangunan

Sumber: Penulis, 2020 


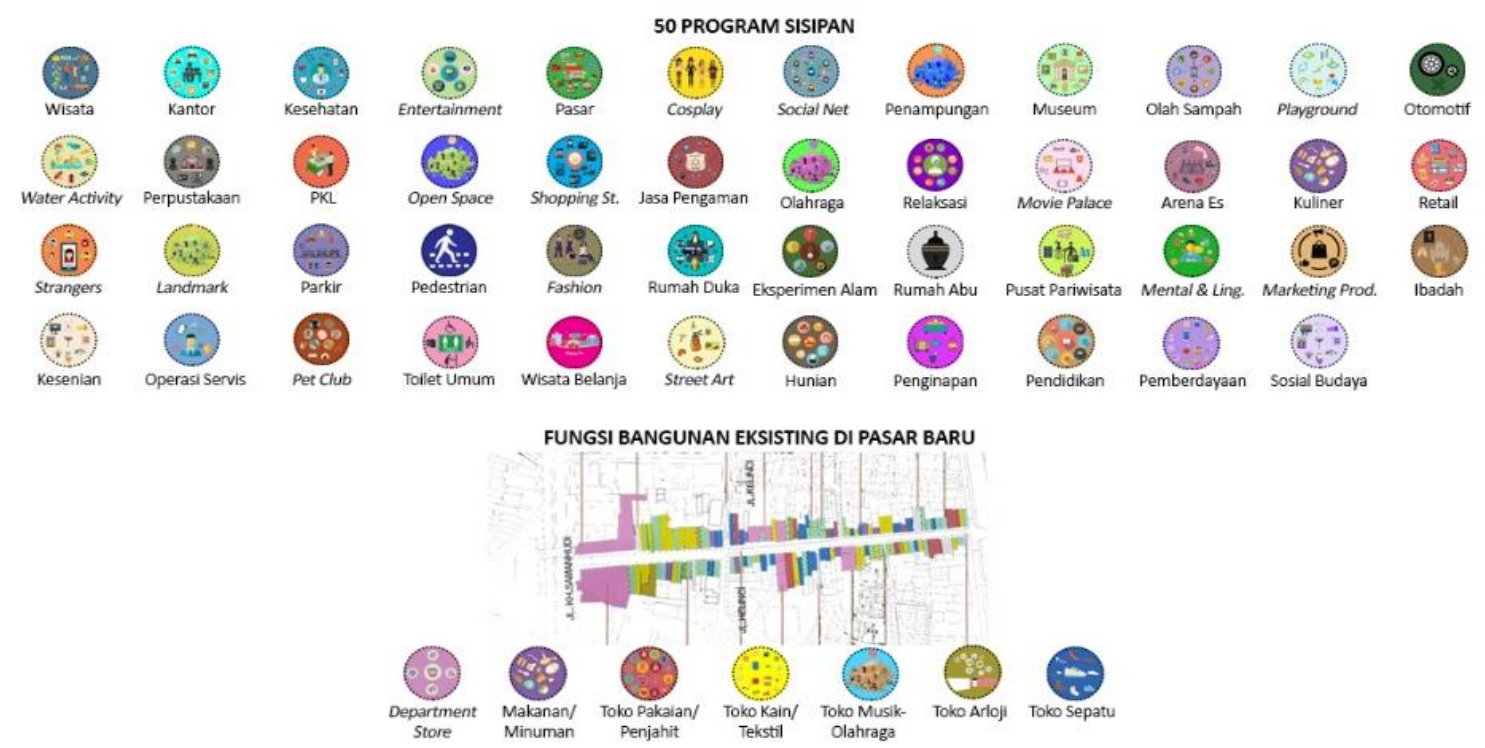

Gambar 6. Program Sisipan dan Eksisting

Sumber: Penulis, 2020

\section{Konsep Transformasi Massa}

Selanjutnya dari program yang sudah didapat dihubungkan keterkaitan antar program menggunakan metode programming cross, trans, dan dis untuk diaplikasikan dalam bentuk transformasi massa berdasarkan tipologi dari masing-masing program.
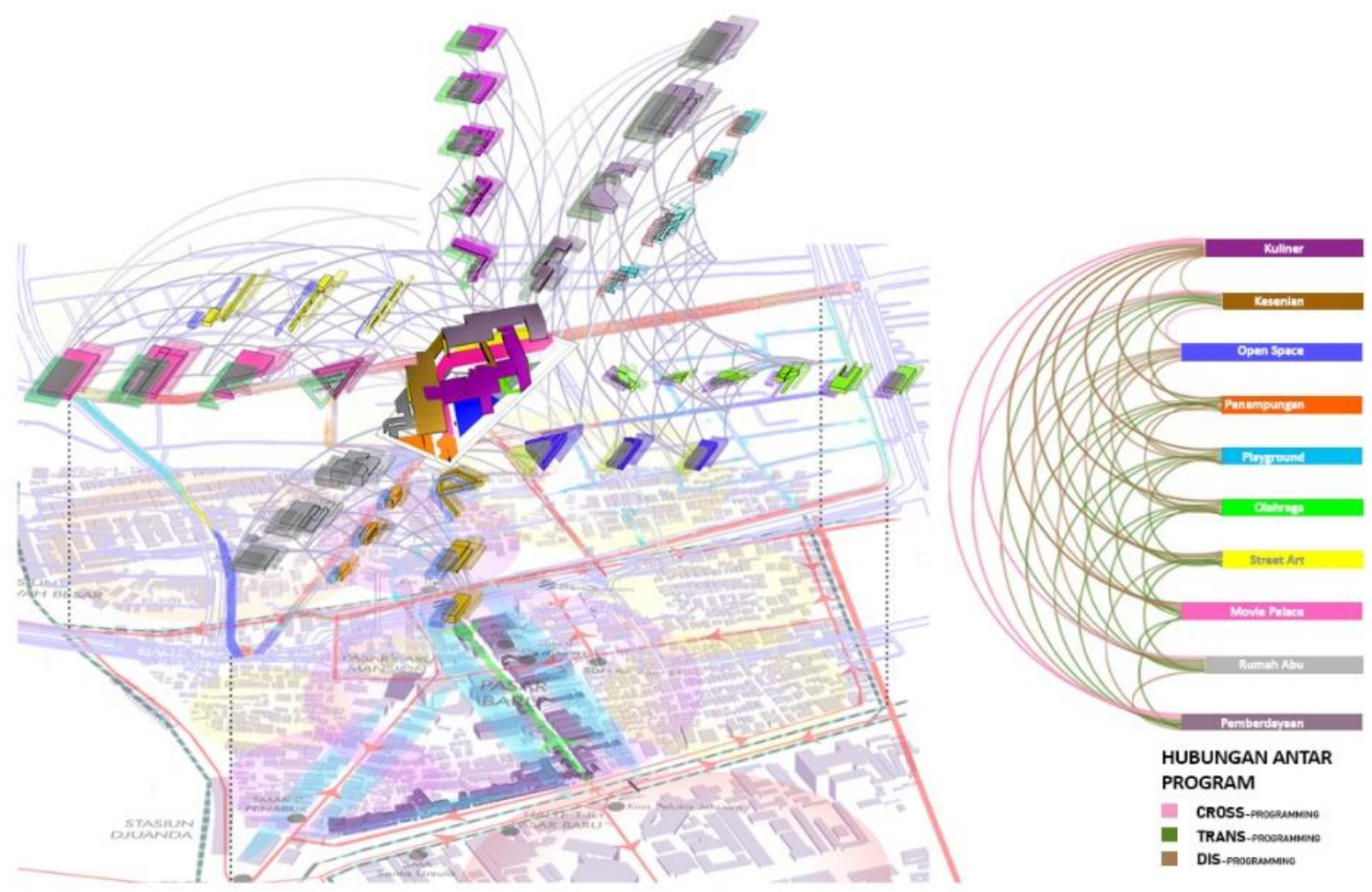

Gambar 7. Konsep Transformasi Massa Sumber: Penulis, 2020 


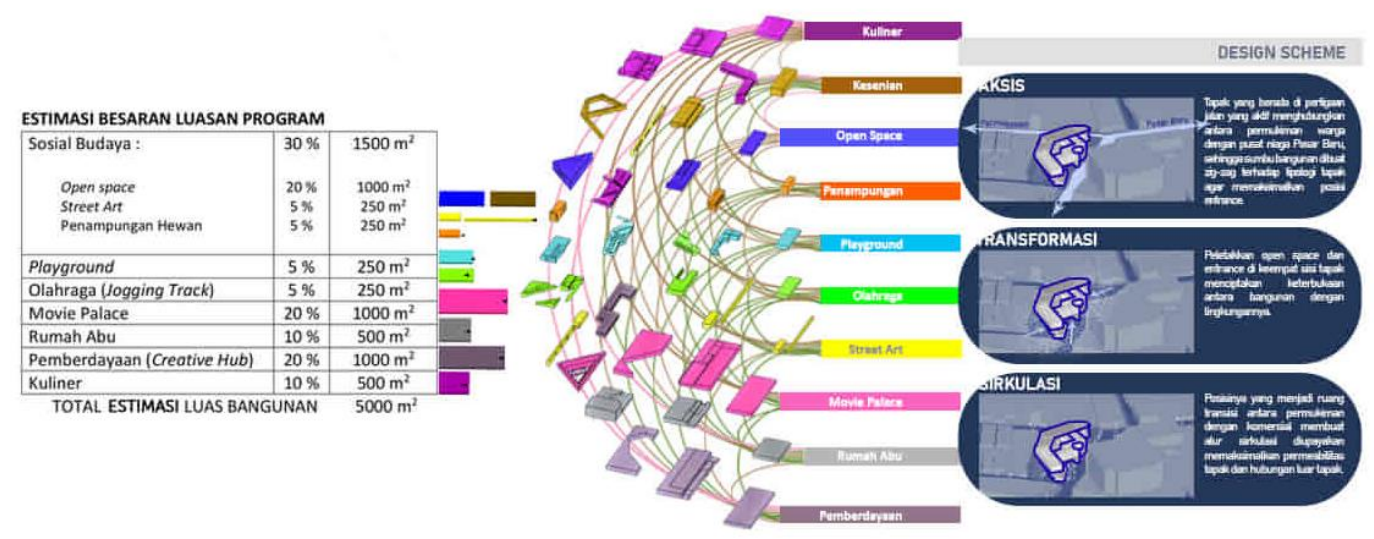

Gambar 8. Proses Transformasi Massa

Sumber: Penulis, 2020

Metode transformasinya berawal dari menentukan besaran luasan program berdasarkan persen estimasi luas bangunan sesuai kebutuhan aktivitas program. Kemudian dari masingmasing program ditentukan tipologinya lalu dikaitkan dengan besaran program tadi. Hasilnya dimasukkan ke dalam bentuk bangunan berdasarkan aksis, bangunan dibuat zig-zag mengikuti orientasi mata angin serta memaksimalkan posisi entrance; transformasi, peletakkan open space dan entrance di keempat sisi tapak menciptakan keterbukaan antara bangunan dengan lingkungannya; sirkulasi, diupayakan memaksimalkan permeabilitas tapak dan hubungan luar tapak.

\section{Konsep Arsitektur: Tipe Unit}

Konsep arsitektur di sini berkaitan dengan tipe unit yang didapat melalui kombinasi antar program dipadukan oleh dua hingga tiga program menjadi satu tipe unit sesuai klasifikasinya yakni cross programming, trans programming, dan dis programming. Unit yang sudah dikombinasikan bisa diduplikasi penempatannya dan ada juga yang dikembangkan lebih lanjut tipenya

Tabel 2. Tipe Unit

\begin{tabular}{lll}
\hline $\begin{array}{l}\text { Tipe } \\
\text { Unit }\end{array}$ & Unit & Jenis Kombinasi \\
Cross programming & Kimensi Unit \\
Trans programming & Kesenian - Street Art
\end{tabular}




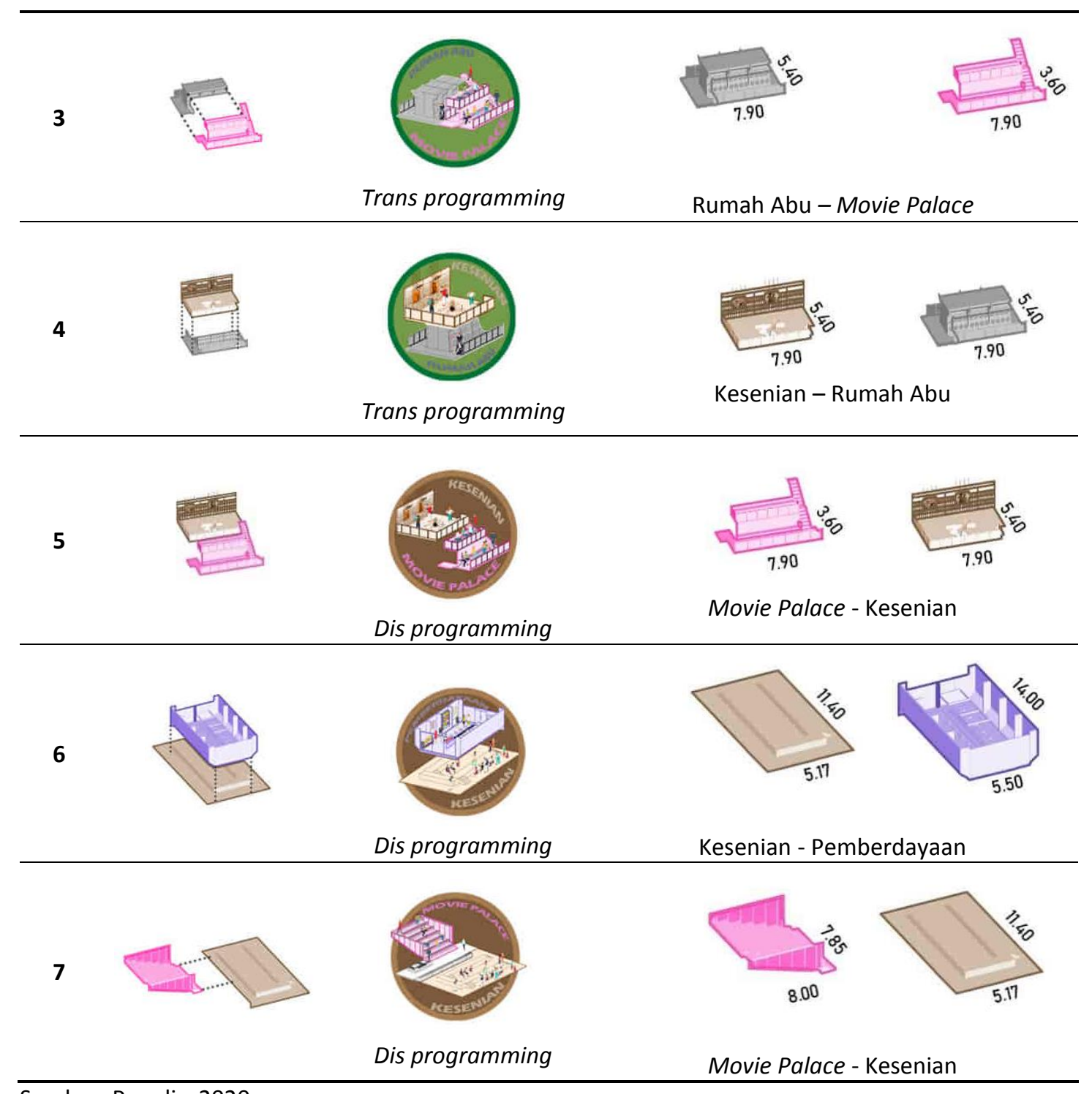

Sumber: Penulis, 2020

Keseluruhan kombinasi program ini diimplementasikan dalam bentuk tipe unit ke dalam bangunan berdasarkan zoning penempatan yang sudah dibentuk dari proses transformasi massa seperti pada gambar 9 . Ketujuh tipe unit yang sudah dikombinasikan disusun menjadi perpaduan duplikasi serta pengembangan yang berlanjut dan tentunya saling berhubungan dalam melangsungkan acara-acara yang nantinya ditentukan pada pembahasan selanjutnya. 


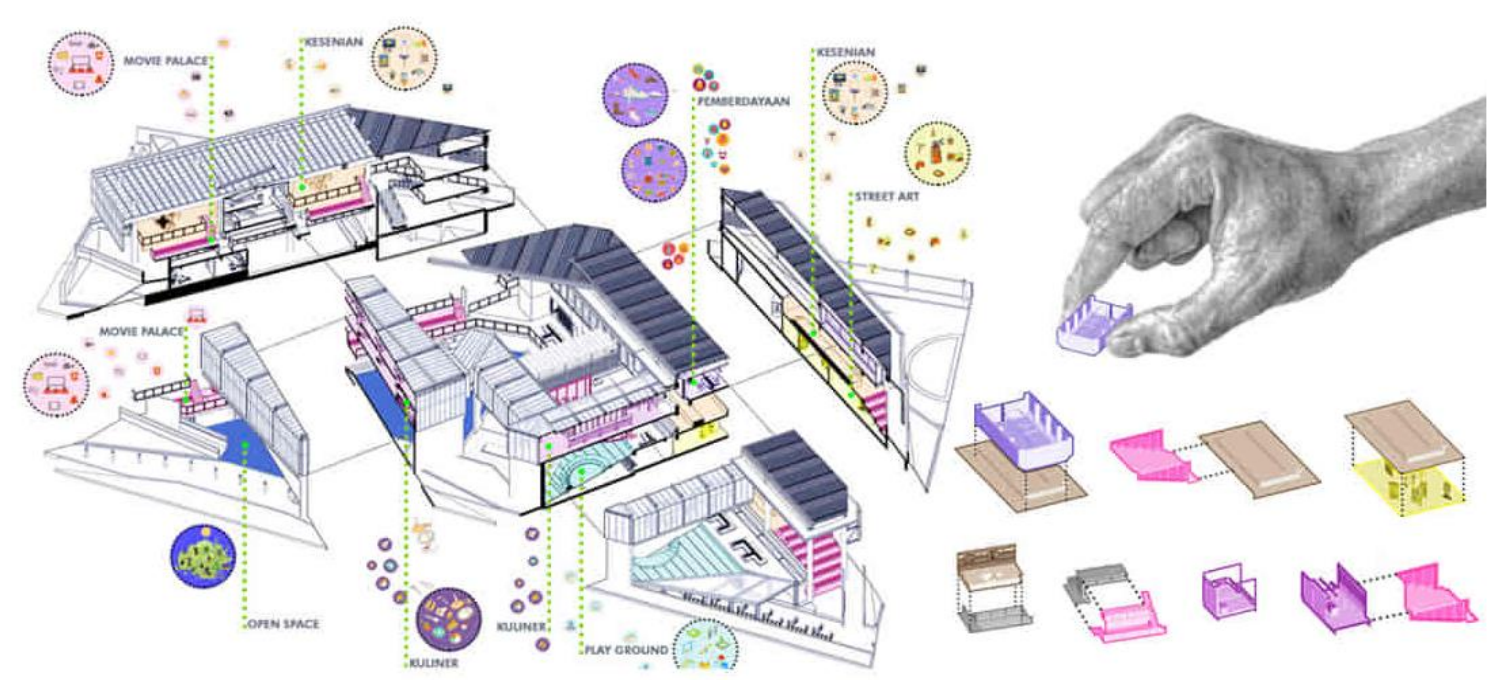

Gambar 9. Implementasi Tipe Unit Sumber: Penulis, 2020

\section{Konsep Arsitektur: Program Bangunan}

Bangunan terdiri atas tiga lantai dengan penempatan program yang sudah ditentukan di awal lalu disisipkan tipe unitnya ke dalam masing-masing zona program yang diduplikasi maupun yang dikembangkan. Guna melengkapi aktivitas keseharian di lingkungan Kelurahan Pasar Baru, tepatnya hampir seluruh warga menginginkan adanya ruang berkumpul, bermain serta hiburan, maka rancangan proyek ini berfokus pada tiga kategori program sebagai berikut.

1. Aktivitas yang terkait dengan penerimaan tamu, pengunjung, dan juga pelayanan terhadap masyarakat (pengguna). Dalam konteks ini fungsi program dapat mewadahi aktivitas warga dalam hal berolahraga, makan, dan bermain.

2. Merespon keunikan daerah merupakan salah satu strategi yang diterapkan dengan mengajak komunitas-komunitas lokal seperti seniman, budayawan, mahasiswa dan pihak lainnya agar terlibat dalam mengadakan festival kegiatan mingguan/ bulanan/ bahkan tahunan didasarkan pada tiap etnis dan budaya.

3. Mengembangkan semangat berwirausaha dengan menciptakan area untuk melakukan produksi segala macam dagangan antara lain tekstil dan kriya sehingga menjadikan area creative hub maupun destinasi wisata heritage baru di Kelurahan Pasar Baru.

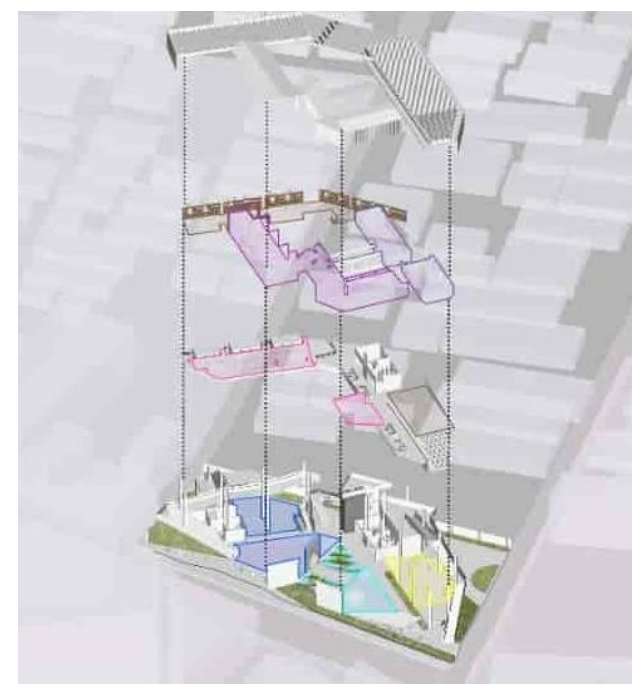

Gambar 10. Zona Unit pada Bangunan Sumber: Penulis, 2020 
Secara garis besar kategori program bangunan terdiri dari area penyambutan, area event, dan eksplorasi kreatif. Keseluruhan program area penyambutan ini berfungsi sebagai pelengkap untuk mewadahi dua kategori program lainnya yang terdiri dari beberapa program guna memfasilitasi keberlangsungan event-event (aktivitas) yang dilakukan oleh pengunjung, yaitu program kuliner, olahraga, dan playground. Area event berupa pengadaan festival dan eventevent lainnya yang berkaitan dengan kesenian, kebudayaan, serta memperingati hari-hari penting merupakan salah satu kategori program utama. Keseluruhan program ini nantinya akan menyediakan plaza (open space) maupun tempat untuk mereka yang akan berlatih mempersiapkan rangkaian acara yang diadakan. Apabila dalam waktu tertentu sedang tidak ada festival, maka plaza tersebut dapat digunakan juga untuk pameran segala bentuk karya seni maupun hasil produk kerajinan serta bisa juga untuk panggung live music. Eksplorasi Kreatif dalam kategori program selanjutnya memfasilitasi pengunjung untuk bereksplorasi dan membentuk kreativitas dalam rangka pemberdayaan usaha untuk generasi muda agar bisa mandiri membuka usaha. Program pemberdayaan ini mengedepankan prinsip transparansi, di mana pengunjung lainnya bisa melihat dan bisa tertarik untuk berpartisipasi. Hasil dari kerajinan mereka bisa dipamerkan maupun dijual di pelataran plaza.

\section{Konsep Event}

Kombinasi antar program menghasilkan event-event yang bisa diselenggarakan baik secara tahunan, bulanan, maupun harian berdasarkan program-program yang dapat berperan mengisi setiap waktu acara. Sehingga keseluruhan aktivitas yang dilakukan di proyek ini memiliki program yang dapat berubah sesuai dengan perubahan waktu. Event-event yang diadakan setiap bulannya terdapat sepuluh jenis acara seperti pada gambar 11. Akan tetapi, tidak seluruh acara dilaksanakan, tergantung juga hari-hari khusus pada event tahunan. Jadi ketika akan diadakan salah satu dari acara bulanan tersebut, program sisipan yang berhubungan akan mewakili setiap waktu acara dan keseluruhan program yang lainnya dapat terus dilaksanakan setiap waktu hingga malam hari sesuai durasi waktu yang sudah ditentukan. 

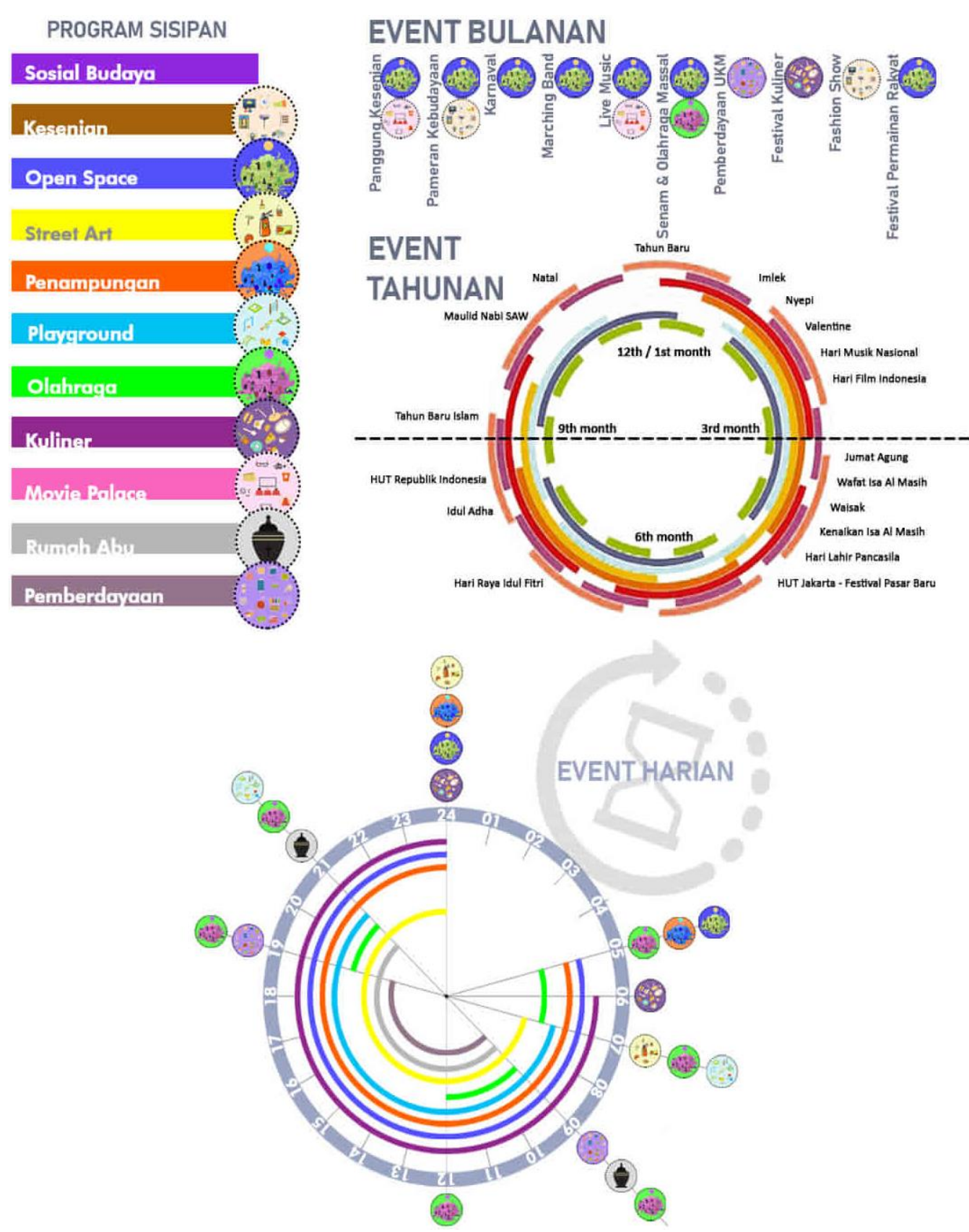

Gambar 11. Aktivitas Terkait pada Bangunan

Sumber: Penulis, 2020

\section{KESIMPULAN DAN SARAN Kesimpulan}

Kebutuhan tempat ketiga di suatu kota saat ini sudah bukan sekadar kebutuhan biasa, melainkan hampir menjadi gaya hidup. Fenomena tempat ketiga berdampak pada penggunaan ruang luar yang pada awalnya dari penggunaan ruang dalam, mulai beralih ke ruang luar/ruang publik sehingga menciptakan event-event tersendiri. Event di sini bukanlah event besar yang dilangsungkan dengan persiapan khusus untuk merayakan sesuatu, akan tetapi pemahaman event di sini lebih kepada bagaimana fenomena tersebut hadir didukung oleh ruang yang muncul secara fleksibel. Pada dasarnya, proyek berusaha menghadirkan ruang-ruang yang mampu mewadahi kebutuhan akan ruang berkumpul, bermain serta hiburan warga yang tentunya sudah melalui proses pengamatan dan pencarian informasi dari berbagai sumber, alhasil disimpulkan bahwa pusat kegiatan yang berada di Kelurahan Pasar Baru mulai dari 
pusat perbelanjaan Pasar Baru sampai Lapangan Banteng nyatanya kurang menjangkau permukiman di Kelurahan Pasar Baru, dalam artian proyek tempat ketiga ini berperan sebagai ruang pemersatu atau transisi dari komersial dengan pemukiman. Temuan yang dihasilkan berupa event program yang dapat terus terhubung di setiap waktu melalui program-program yang disisipkan.

Kelebihan dalam merancang proyek tidak menghilangkan atau mengubah secara total berbagai hal yang sudah menjadi karakteristik dari Pasar Baru, akan tetapi dikembangkan serta memberikan lebih banyak pilihan bagi pengunjung untuk mengeksplorasi dan membentuk berbagai event penyegaran di proyek ini sehingga bangunan mampu menjadi stimulus bagi daerah sekitar untuk memperhatikan pentingnya ruang terbuka kota dan ruang terbuka hijau. Dibalik kelebihan dari proyek yang dirancang, terdapat kekurangan akan terbatasnya programprogram yang tidak seluruhnya dapat berkontribusi terhadap event-event yang diselenggarakan. Akan tetapi, konteks ruang arsitektur yang diperoleh berusaha menciptakan arsitektur yang memiliki program yang dapat berubah sesuai dengan perubahan waktu berdasarkan pendekatan fungsi dan ruang terkait dengan aktivitas produktivitas (ukm/inkubator hingga workshop tekstil dan kriya), hiburan (karya seni dan festival), serta aktivitas keseharian warga di sekitar Kelurahan Pasar Baru maupun pendatang. Secara keseluruhan program yang terbentuk menjadi wadah masyarakat untuk semua kalangan usia dalam berkumpul, berolahraga, bermain, mencari hiburan, berekspresi, berwirausaha serta dapat dijadikan aksen untuk menarik pergerakan pengunjung dari first place (rumah) menuju second place (bekerja).

\section{Saran}

Kesibukan masyarakat kota sehari-hari akan membuat mudah jenuh dan menyebabkan munculnya keinginan akan adanya suatu event penyegaran. Arsitektur sebagai bagian dari peran kehidupan perkotaan manusia memiliki kesempatan untuk mengusulkan alternatif keruangan lainnya. Ruang baru tersebut adalah Third Place atau "tempat ketiga", sebuah tempat yang kegiatannya tidak terkait dengan rutinitas sehari-hari. Maka dalam sebuah wilayah sangat dibutuhkan tempat ketiga agar masyarakatnya dapat saling melepas kepenatan dari aktivitas kesehariannya, bertemu dan membangun ruang dialog agar menghidupkan kembali suasana kota baik itu pagi, siang, maupun malam hari.

\section{REFERENSI}

Bonnemaison, S., \& Masy, C. (2008). Festival Architecture. Abingdon: Routledge.

Certeau, M. d. (1984). The Practice of Everyday Life. Berkeley: University of California Press.

Daniel, L. C., Mary, C. L., Grove, J. M., Marshall, V., McGrath, B., \& Pickett, S. T. (2015). An Ecology for Cities: A Transformational Nexus of Design and Ecology to Advance Climate Change Resilience and Urban Sustainability.

Fikri, M. N. (2016). Perancangan Pusat Terapi Kesehatan dengan Musik. S.T. Universitas Islam Negeri Maulana Malik Ibrahim.

Hantono, D., \& Ariantantrie, N. (2018). Kajian Ruang Publik dan Isu yang Berkembang di dalamnya. Jurnal Arsitektur, Bangunan, dan Lingkungan, 8, 43-48.

Hawking, S. (1988). The Brief History of Time.

Herlambang, S. (2020, Januari 16). Open Society-Open City-Open Architecture. Dipresentasikan pada kuliah umum, Universitas Tarumanagara.

Indra, M. I. (2009). Pengembangan Pasar Baru Jakarta. Jurnal Fakultas Teknik, Universitas Indonesia.

Mardiyantoro, N. (2019). Metodologi Penelitian. E-learning Fakultas Teknik dan IImu Komputer, Universitas Sains Al-Qur'an, 1-22.

Noor, A. (2009). Manajemen Event. Bandung: Alfabeta. 
Nurun, M. (2013). Revitalisasi Kawasan Pasar Baru Sebagai Upaya untuk Meningkatkan Keunggulan Bersaing Pusat Belanja Tertua di Jakarta. Jurnal Perencanaan Wilayah dan Kota, 4, 69-78.

Oldenburg, R. (1989). The Great Good Place: Cafes, Coffee Shops, Community Centers, Beauty Parlors, General Stores, Bars, Hangouts, and How They Get You Through the Day. New York: Paragon House.

Pasya, G. K. (2012). Pemukiman Penduduk Perkotaan. Jurnal Pendidikan Geografi, 12, 61-70.

Pidarta, M. (2015). Perencanaan Pendidikan Partisipatori dengan Pendekatan Sistem. Jakarta: Rineka Cipta.

Rieswari, A. (2002). Penataan Koridor Jalan Pasar Baru Jakarta. S.T. Universitas Diponegoro Semarang.

Septian, L. H., Kurniati, F., \& Maharika, I. F. (2017). Konfigurasi Ruang Bertinggal di Perahu Suku Bajo. Prosiding Temu IImiah Ikatan Peneliti Lingkungan Binaan Indonesia 6, (pp. 57-62).

Setiawan, L. A., Astuti, W., \& Rini, E. F. (2017). Tingkat Kualitas Permukiman (Stusi Kasus: Permukiman Sekitar Tambang Galian C Kecamatan Weru, Kabupaten Sukoharjo. Jurnal Perencanaan Wilayah dan Kota, 12, 1-11.

Statistik, B. P. (2016). Potret Awal Tujuan Pembangunan Berkelanjutan (Sustainable Development Goals) di Indonesia. 07330.1701. Retrieved Januari 15, 2020, from https://filantropi.or.id/pubs/uploads/files/BPSPotretAwalTPBdilndonesia.pdf

Sutanto, A. (2020, Januari 16). Architecture of the Third Place. Dipresentasikan pada kuliah umum, Universitas Tarumanagara.

Tschumi, B. (1994). Architecture and Disjuction. England: MIT Press.

Tschumi, B. (2005). Event-Cities 3: Concept vs Context vs Content. Massachussetts: MIT Press, Cambridge.

Wicaksono, B. (2014). Penataan Pasar Baru.

Winata, S. (2019). Open Architecture As. Dipublikasikan pada pameran arsitektur virtual STUPA 8.29, Universitas Tarumanagara: 4 Juli 2020

Yusa, M. M. (2016). Upside down Building: Suatu Karya Dekonstruksi Desain Arsitektur. Jurnal Studi Kultural, 1, 65-69. 